\title{
Maize plants produce direct resistance elicited by Tetranychus urticae Koch (Acari: Tetranychidae)
}

\author{
P. D. Paulo ${ }^{a}$, C. G. Lima ${ }^{a}$, A. B. Dominiquini ${ }^{a}$, M. A. M. Fadini ${ }^{*}$, S. M. Mendes ${ }^{b}$ and \\ C. G. S. Marinho ${ }^{a}$ \\ ${ }^{a}$ Department of Agricultural Science, Universidade Federal de São João del-Rei - UFSJ, Rod MG 424, \\ Km 47, CEP 35701-970, Sete Lagoas, MG, Brazil

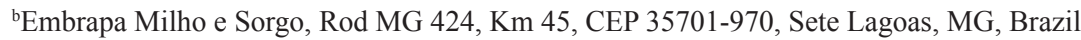 \\ *e-mail: fadini@ufsj.edu.br
}

Received: November 24, 2015 - Accepted: August 12, 2016 - Distributed: February 28, 2018

(With 1 figure)

\begin{abstract}
Plants can be attacked by a wide variety of herbivores. Thus, developing protective mechanisms for resistance against these agents is an advantage for survival and reproduction. Over the course of evolution, many resistance mechanisms against herbivory have been developed by the plants. Induced direct and indirect resistance mechanisms can manifest in plants after herbivore attack. The two-spotted spider mite Tetranychus urticae is not a pest of maize crops (Zea mays), despite being reported infesting plants that may have resistances against this herbivore. We tested the hypothesis that maize plants would be able to induce direct resistance against $T$. urticae after, evaluating the effect of T. urticae infestation in maize plants on the development and reproduction of conspecifics. We tested induced direct resistance performing infestation and measuring biological parameters upon a second infestation. Maize plants, 40 days after sowing, were divided into two groups: 30 not infested by T. urticae (clean plants clean) and, 30 infested by the spider mite. Infestation of maize plants by T. urticae reduced the conspecific female adult survival. However, no change in the survival of immature or reproduction was observed. These results suggest the induction of induced direct resistances in maize by T. urticae. This is first report of direct resistance induction in Z. mays by the two-spotted spider mite T. urticae.
\end{abstract}

Keywords: plant resistance, induced resistance, constitutive resistance, two-spotted spider mite, Zea mays.

\section{Plantas de milho produz resistência elicitada por Tetranychus urticae Koch (Acari: Tetranychidae)}

\begin{abstract}
Resumo
As plantas podem ser atacadas por uma grande diversidade de herbívoros. Sendo assim, o desenvolvimento de mecanismos de proteção para se defenderem destes agentes é um diferencial para a sobrevivência e reprodução. Ao longo da evolução, diversos mecanismos de resistência contra herbívoria foram desenvolvidos pelas plantas. Mecanismos de resistência induzida direta e indireta podem manifestar-se em plantas após o ataque de herbívoros. O ácaro-rajado Tetranychus urticae não é uma praga na cultura da cultura do milho (Zea mays), apesar de ser relatado infestando plantas, as quais podem apresentar resistências contra tal herbívoro. Testamos a hipótese de que plantas de milho seriam capazes de induzir resistências diretas à T. urticae após o ataque, avaliando o efeito da infestação de $T$. urticae de plantas em milho sobre seu desenvolvimento e reprodução de coespecíficos. Testamos resistência induzida direta realizando uma infestação e medindo os parâmetros biológicos em uma segunda infestação. Plantas de milho foram divididas em dois grupos: 30 plantas não por T. urticae (plantas limpas) e 30 plantas infestadas pelo ácaro-rajado. A infestação de plantas de milho por T. urticae reduziu a sobrevivência de fêmeas adultas do coespecífico. Entretanto, não foi observada alteração na sobrevivência das formas imaturas ou reprodução. Tais resultados sugerem a indução de resistências induzida diretas em milho por T. urticae. Este é primeiro relato de indução de resistência direta em Z. mays pelo ácaro-rajado T. urticae.
\end{abstract}

Palavras-chave: resistência de planta, resistência induzida, resistência constitutiva, ácaro-rajado, Zea mays.

\section{Introduction}

A wide diversity of herbivore species infests plants. Thus, over evolutionary time plants have developed constitutive and induced responses against these enemies (Price et al.,
1980; Karban and Baldwin, 1997). The constitutive resistances operate continuously, complicating herbivore feeding through cuticular deposits, thickened epidermis 
and abundance of crystals, thorns, trichomes and fibers in the lea (Becerra, 1994). The chemical responses, such as toxic metabolites and/or repellents act, for example, minimizing damage by reducing the palatability of the plants or by toxic effects in the herbivores (Arimura et al., 2005).

Induced responses that reduce the herbivore survival and reproduction are termed as induced resistance (Karban and Baldwin, 1997). Induced resistances can be classified as induced direct resistance, that directly affect the herbivore biology (Schaller, 2008) and induced indirect resistance, which affects herbivores by promoting the attraction of natural enemies, as predators and parasitoids (Arimura et al., 2005; Dicke et al., 2009; Castro et al., 2014). The induced direct resistance against herbivores, for example, affects the production of secondary metabolites, substances involved in plant resistance mechanisms (Karban and Baldwin, 1997). For example, protease inhibitors and phytoalexins, directly affect the herbivore survival (Howe and Jander, 2008; Ryan, 1990). The responses of plants to herbivore attack can reduce subsequent herbivory via induced resistance (Karban and Carey, 1984; Agrawal et al., 2000). Thus, damage to part of the plant results in a systemic response, release of volatile compounds and, biochemical cascade into the plant (Moraes et al., 2000). Previous studies have reported direct resistance induction by Tetranychus urticae Koch (Acari: Tetranychidae) in plants, resulting in reduced performance of these organisms in previously infested plants (Karban and Carey, 1984; Kant et al., 2004).

The two-spotted spider mite, T. urticae, is a polyphagous herbivore of great economic importance in many crops, having a host range of more than 1,100 species of plants (Grbić et al., 2011). Nevertheless, the technical literature that recommends pest management strategies in maize (Zea mays L., Poaceae) in Brazil still does not refer to records of mite populations that have reached pest status (Fadini et al., 2010). Surveys of the species incidence and studies on mites as pests in maize are scarce (Moraes and Flechtmann, 2008; Fadini et al., 2012). Despite showing little importance as maize pests, herbivore tetranychide mites, and even eriophyoidea ones are endemically present and their populations can eventually increase when them find favorable resources and conditions and achieve pest status (Cruz et al., 2008).

The study of plant resistance is critical to the elucidation of factors that affect the arthropod community (e.g. herbivores and predators) in agroecosystems. The comprehension of the resistance mechanisms of plants facilitates the development of pest-resistant cultivars, as well as determination of biochemical and evolutionary relationships between plants and herbivores (Welling, 2001; Bale et al., 2008; Chen, 2008). There are no examples in literature about direct resistance in $Z$. mays induced by phytophagous mites. Therefore, the biochemical routes into the plant and ecological consequences in food web are a not studied area yet.

We tested the hypothesis that maize plants would be able to directly induce resistance to $T$. urticae after infestation. To test this hypothesis, we evaluated the effect of pre-infestation of maize plants by $T$. urticae on development and reproduction of conspecifics upon reinfestation.

\section{Material and Methods}

The experiment was conducted in a greenhouse and laboratory from December 2013 to February 2014. To verify the possibility of direct resistance induction in maize plants, we assessed the population growth of T. urticae on maize plants infested by conspecifics and on plants not previously infested.

\subsection{Stock cultures of mites}

Individuals of $T$. urticae were obtained from the leaves of maize Z. mays at Embrapa Milho e Sorgo, in Sete Lagoas, Minas Gerais State. Approximately 1,000 adults were removed from the leaves with a brush and transferred to seedlings of the bean Phaseolus vulgaris L (Poaceae), due to facilities to maintain this plant; the spider mites have a good performance on bean (Moraes and Flechtmann, 2008). Bean seed was sown in 500-gram plastic pots, using Terral Solo ${ }^{\circledR}$ substrate and kept isolated in screened cages. The rearing occurred in a greenhouse under natural conditions. Every 5 days, two new bean plants were added to maintain the population. Uninfested bean plants were also kept in a greenhouse and added to the rearing of the T. urticae mites, according to the need for plants for more infestations.

\subsection{Maize plant infestation}

The maize seeding occurred on December 21, 2013, in 500 g plastic pots, using Terral Solo ${ }^{\circledR}$ substrate and kept in a greenhouse. The maize seed planted was the conventional hybrid 30F35. Two seeds were sown per pot and thinned after two weeks to only one maize seedling per pot. Seven days after sowing the maize plants were fertilized with $0.2 \mathrm{~g}$ of ammonium sulfate per pot. The plants were kept in screened cages to prevent infestation by herbivores.

The two treatments evaluated were 30 uninfested plants (hereafter clean plants) and 30 plants infested with the two-spotted spider mite T. urticae (hereafter infested plants). A single infestation was conducted in maize plant group composed of clean plants. For each plant, a leaf on the abaxial face was infested with 10 females of $T$. urticae during five days that were maintained within a barrier made using entomological glue Biocontrole ${ }^{\circledR}$ to prevent escape. The infested leaves were marked for future identification. Entomological glue did not affect the plant.

Five days after the infestation, 10 females of T. urticae were set in infested and clear plants, and the leaves were marked. In infested plants, the spider mites were put in a non-infested leaf. The first infestations were kept on the plants. We evaluated the survival and reproduction of 10 spider mites females in infested and clean plants as follows.

Five days after the last infestation a random drawing of the plants to be evaluated in the group of infested and clean plants was conducted. The pots, numbered from 1 to 30 , 
were drawn for a once-only reading of the plants, so that each maize plant became an independent sampling unit. Counting was done by removing the leaves from the previously drawn plants, identified and cut at its extremity with scissors and taken to the laboratory for viewing under magnifying glass (40X). The evaluations were conducted for 15 days, reading a total of two individuals per treatment (infested and clean plants) in each day. For each individuals one leaf were removed and daily we evaluated the number of live and dead females, the number of immatures and the number of eggs. For statistical, all measure in each day were the average of two plants.

\subsection{Statistical analyses}

Generalized Linear Models (GLM) with a negative binomial distribution were used for data analysis. This distribution is justified when the relationship between mean and variance is greater than one. The main independent variable (x) was the infestation by T. urticae and the time after the infestation. The dependent variables (y) were the number of living female mites, number of immature and number of T. urticae eggs. The fit of the models was evaluated by residual analysis and compliance tests. The $\mathrm{R}$ program (R Development Core Team, 2014) was used for exploratory analysis and statistical data. The package MASS was used to adjust models with negative binomial distribution for aggregated data. To test de adjustment of statistical models, the experimental error will be tested for the random distribution.

\section{Results and Discussion}

The infested plants showed a reduced the number of adult females when compared with the clean plants. In both treatments the number adult females reduced over time with a higher reduction rate in infested plants $\left(\chi^{2}=3.2\right.$, $\mathrm{df}=1, \mathrm{p}=0.003$; Figure 1A). However, the number of immatures $\left(\chi^{2}=1.0, \mathrm{df}=1, \mathrm{p}=0.323\right.$; Figure 1B) and the number of eggs $\left(\chi^{2}=0.8, \mathrm{df}=1, \mathrm{p}=0.390\right.$; Figure $\left.1 \mathrm{C}\right)$ were not affected by treatments.

The infestation in maize plants by phytophagous mites reduced the number of conspecific individual adults a second infestation. These results suggest that plants undergoing prior infestations by T. urticae are able to induce direct resistances to injury compared to those that were not attacked (Baldwin and Schmelz, 1996). However, additional chemical analysis on infested and clean plants is necessary to confirm this hypothesis. Karban and Carey (1984) reported the induction of direct resistance by T. urticae in cotton plants, resulting in reduced performance of these phytophagous mites on previously attacked plants. In agreement with the direct resistance induction in maize plants by $T$. urticae hypothesis, studies conducted with tomato plants suggested that the two-spotted spider mite, T. urticae, induces direct resistance in tomato regulated by jasmonates (Li et al., 2002; Kant et al., 2004; Smart et al., 2013). Szczepaniec et al. (2013) noted an increase in resistance gene expression induced by phytophagous mites, as well as gene expression related to induced resistance and population reduction of T. urticae in tomato plants, maize and cotton. This present study also corroborates the findings, strongly suggesting the induction of direct resistance by T. urticae in maize plants.

However, the infestation of T. urticae in maize plants did not affect the number of immatures and the number of eggs of conspecifics compared to those maintained on clean plants. This possibly occurred because the resistances elicited in the plants act more quickly on the adult survival than on their reproduction. Fadini et al. (2004) did not observe changes in biological parameters of T. urticae in induced direct response in strawberry plants. One possible explanation for this result may also be due to the exposure time being insufficient to impair the juveniles. Maeda and Ishiwari (2012) tested the effect of Tianidil, an activator that induces resistances in Camellia sinensis (Theaceae) plants as a mechanism against herbivores, and they did not verify reductions in the oviposition rate, immature stage duration and sex ratio of the mite $T$. kanzawai. One hypothesis is that the induced direct resistances would affect adult females
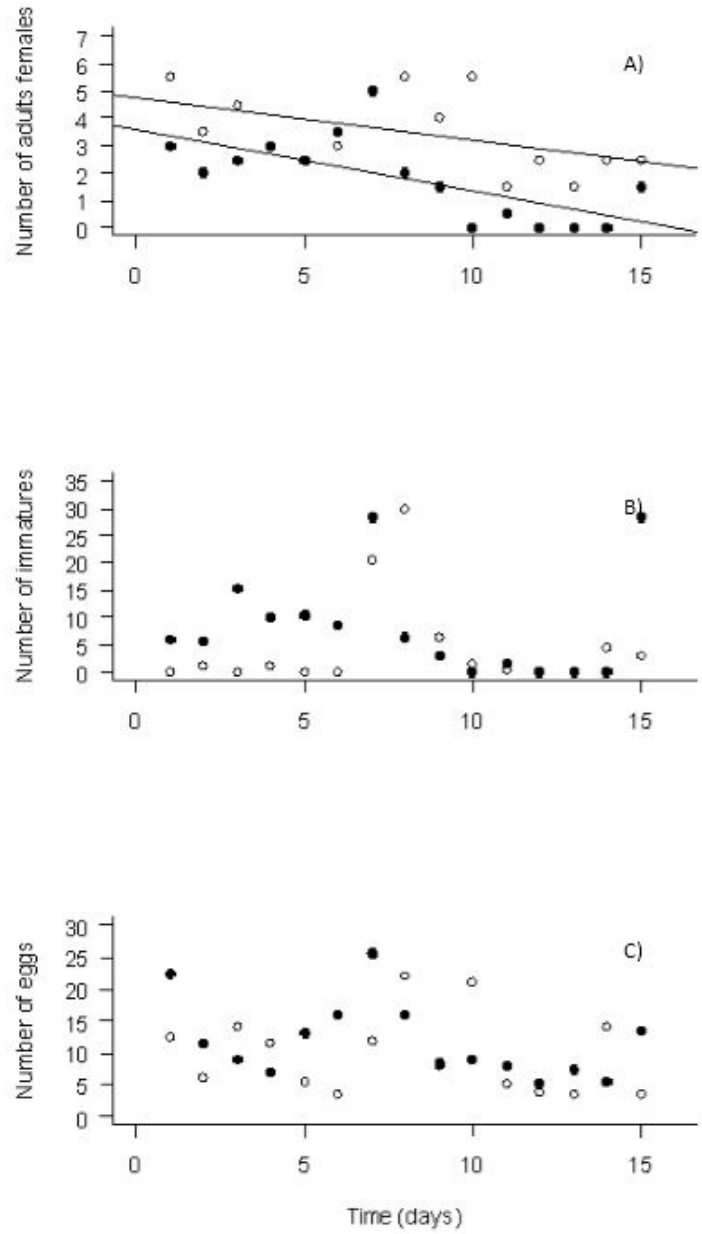

Figure 1. Mean of adult female (A), immatures (B), and eggs (C) of Tetranychus urticae on clean (o) and infested $(\bullet)$ maize plants recorded during 15 days. 
since they fed on the plants. However, the exposure time to the resistance was not enough to change reproduction related parameters (i.e. number of eggs and number of immature forms), as mentioned. Another hypothesis for the results obtained can be related to the developmental stage in which the plants were found (Boege and Marquis, 2005).

This is first report suggesting direct resistance induction in maize by the two-spotted spider mite T. urticae. It can serve to guide future studies, from which more conclusive information about the biochemical mechanisms involved this kind of resistance. Although T. urticae is not regarded as an abundant and damaging herbivore in maize, resistance induction can come a management component and minimize any injuries caused by this herbivore. Resistance induction may prove to be a component of herbivore mite integrated management in maize.

\section{Acknowledgements}

Financial support and scholarships were provided by the National Council of Scientific and Technological Development (CNPq) and by the Minas Gerais State Foundation for Research Aid (FAPEMIG).

\section{References}

AGRAWAL, A.A., KARBAN, R. and COLFER, R.G., 2000. How leaf domatia and induced plant resistance affect herbivores, natural enemies and plant performance. Oikos, vol. 89, no. 1, pp. 70-80. http://dx.doi.org/10.1034/j.1600-0706.2000.890108.x.

ARIMURA, G., KOST, C. and BOLAND, W., 2005. Herbivoreinduced, indirect plant defences. Biochimica et Biophysica Acta, vol. 1734, no. 2, pp. 91-111. PMid:15904867. http://dx.doi. org/10.1016/j.bbalip.2005.03.001.

BALDWIN, I.T. and SCHMELZ, E.A., 1996. Immunological "memory" in the induced accumulation of nicotine in wild tobacco. Ecology, vol. 77, no. 1, pp. 236-246. http://dx.doi. org/10.2307/2265673.

BALE, J.S., VAN LENTEREN, J.C. and BIGLER, F., 2008. Biological control and sustainable food production. Philosophical Transactions of the Royal Society of London. Series B, Biological Sciences, vol. 363, no. 1492, pp. 761-776. PMid:17827110. http:// dx.doi.org/10.1098/rstb.2007.2182.

BECERRA, J.X., 1994. Squirt-gun defense in Bursera and the chrysomelid counterploy. Ecology, vol. 75, no. 7, pp. 1991-1996. http://dx.doi.org/10.2307/1941603.

BOEGE, K. and MARQUIS, R.J., 2005. Facing herbivory as you grow up: the ontogeny of resistance in plants. Trends in Ecology \& Evolution, vol. 20, no. 8, pp. 441-448. PMid:16701415. http:// dx.doi.org/10.1016/j.tree.2005.05.001

CASTRO, B.M.C., SOARES, M.A., ANDRADE JÚNIOR, V.C., FADINI, M.A.M., FERREIRA, J.A.M. and MORAES, G.J., 2014. The predatory mite Phytoseiulus macropilis (Acari: Phytoseiidae) occurring on sweet potato (Ipomoea batatas) plants in Diamantina, Minas Gerais State, Brazil. Brazilian Journal of Biology $=$ Revista Brasileira de Biologia, vol. 74, no. 3, pp. 685686. PMid:25296218. http://dx.doi.org/10.1590/bjb.2014.0078.
CHEN, M.S., 2008. Inducible direct plant defense against insect herbivores: A review. Journal of Insect Science, vol. 15, no. 2, pp. 101-114. http://dx.doi.org/10.1111/j.1744-7917.2008.00190.x.

CRUZ, I., VALICENTE, F.H., SANTOS, J.P., WAQUIL, J.M. and VIANA, P.A., 2008. Manual de identificação de pragas do milho e de seus principais agentes de controle biológico. Sete Lagoas: Embrapa Milho e Sorgo. 166 p.

DICKE, M., VAN LOON, J.J. and SOLER, R., 2009. Chemical complexity of volatiles from plants induced by multiple attack. Nature Chemical Biology, vol. 5, no. 5, pp. 317-324. PMid:19377458. http://dx.doi.org/10.1038/nchembio.169.

FADINI, M.A.M., ARAUJO, O.G., MENDES, S.M. and MARINHO, C.G.S., 2012. Ocorrência do ácaro fitófago Catarhinus tricholaenae Keifer (Acari: Diptilomiopidae) em cultivares de milho Bt. Ciência Rural, vol. 42, no. 9, pp. 1524-1527. http:// dx.doi.org/10.1590/S0103-84782012000900001.

FADINI, M.A.M., LEMOS, W.P., PALLINI, A., VENZON, M. and MOURÃO, A.S., 2004. Herbivoria de Tetranychus urticae Koch (Acari: Tetranychidae) induz defesa direta em morangueiro? Neotropical Entomology, vol. 33, no. 3, pp. 293-297. http://dx.doi. org/10.1590/S1519-566X2004000300003.

FADINI, M.A.M., MENDES, S.M., ARAUJO, O.G. and WAQUIL, J.M., 2010. Os ácaros são pragas do milho no Brasil? Sete Lagoas: Embrapa Milho e Sorgo. 14 p.

GRBIĆ, M., VAN LEEUWEN, T., CLARK, R.M., ROMBAUTS, S., ROUZÉ, P., GRBIĆ, V., OSBORNE, E.J., DERMAUW, W., NGOC, P.C., ORTEGO, F., HERNÁNDEZ-CRESPO, P., DIAZ, I., MARTINEZ, M., NAVAJAS, M., SUCENA, É., MAGALHÃES, S., NAGY, L., PACE, R.M., DJURANOVIĆ, S., SMAGGHE, G., IGA, M., CHRISTIAENS, O., VEENSTRA, J.A., EWER, J., VILLALOBOS, R.M., HUTTER, J.L., HUDSON, S.D., VELEZ, M., YI, S.V., ZENG, J., PIRES-DASILVA, A., ROCH, F., CAZAUX, M., NAVARRO, M., ZHUROV, V., ACEVEDO, G., BJELICA, A., FAWCETT, J.A., BONNET, E., MARTENS, C., BAELE, G., WISSLER, L., SANCHEZ-RODRIGUEZ, A., TIRRY, L., BLAIS, C., DEMEESTERE, K., HENZ, S.R., GREGORY, T.R., MATHIEU, J., VERDON, L., FARINELLI, L., SCHMUTZ, J., LINDQUIST, E., FEYEREISEN, R. and VAN DE PEER, Y., 2011. The genome of Tetranychus urticae reveals herbivorous pest adaptations. Nature, vol. 479, no. 7374, pp. 487-492. PMid:22113690. http://dx.doi.org/10.1038/nature10640.

HOWE, G.A. and JANDER, G., 2008. Plant immunity to insect herbivores. Annual Review of Plant Biology, vol. 59, no. 1, pp. 41-66. PMid:18031220. http://dx.doi.org/10.1146/annurev. arplant.59.032607.092825.

KANT, M.R., AMENT, K., SABELIS, M.W., HARING, M.A. and SCHUURINK, R.C., 2004. Differential timing of spider mite induced direct and indirect defenses in tomato plants. Plant Physiology, vol. 135, no. 1, pp. 483-495. PMid:15122016. http:// dx.doi.org/10.1104/pp.103.038315.

KARBAN, R. and BALDWIN, I.T., 1997. Induce responses to herbivory. Chicago: University of Chicago Press. 317 p.

KARBAN, R. and CAREY, J.R., 1984. Induced resistance of cotton seedlings to mites. Science, vol. 225, no. 4657, pp. 53-54. PMid:17775661. http://dx.doi.org/10.1126/science.225.4657.53.

LI, C., WILLIAMS, M.M., LOH, Y.T., LEE, G.I. and HOWE, G.A., 2002. Resistance of cultivated tomato to cell content-feeding herbivores is regulated by the octadecanoid-signaling pathway. Journal of Plant Physiology, vol. 130, no. 1, pp. 494-503. PMid:12226528. http://dx.doi.org/10.1104/pp.005314. 
MAEDA, T. and ISHIWARI, H., 2012. Tiadinil, a plant activator of systemic acquired resistance, boosts the production of herbivoreinduced plant volatiles that attract the predatory mite Neoseiulus womersleyi in the tea plant Camellia sinensis. Experimental \& Applied Acarology, vol. 58, no. 3, pp. 247-258. PMid:22669277. http://dx.doi.org/10.1007/s10493-012-9577-2.

MORAES, C.M., LEWIS, W.J. and TUMLINSON, J.H., 2000. Examining plant-parasitoid interactions in tritrophic systems. Anais da Sociedade Entomológica Brasil, vol. 29, no. 2, pp. 189-203. http://dx.doi.org/10.1590/S0301-80592000000200001.

MORAES, G.J. and FLECHTMANN, C.H.W., 2008. Manual de acarologia, acarologia básica e ácaros de plantas cultivadas no Brasil. Ribeirão Preto: Holos Editora. 308 p

PRICE, P.W., BOUTON, C.E., GROSS, P., MCPHERON, B.A., THOMPSON, J.N. and WEIS, A.E., 1980. Interactions among three trophic levels: influence of plants on interactions between insect herbivores and natural enemies. Annual Review of Ecology and Systematics, vol. 11, no. 1, pp. 41-65. http://dx.doi.org/10.1146/ annurev.es.11.110180.000353.

R DEVELOPMENT CORE TEAM, 2014 [viewed 24 November 2016]. R: a language and environment for statistical computing [online]. Vienna: R Foundation for Statistical Computing. Available from: http://www.R-project.org

RYAN, C.A., 1990. Protease inhibitors in plants: genes for improving defenses against insects and pathogens. Annual Review of Phytopathology, vol. 28, no. 1, pp. 425-449. http://dx.doi. org/10.1146/annurev.py.28.090190.002233.

SCHALLER, A., 2008. Induced plant resistence to herbivore. Germany: Springer. 462 p.

SMART, L.E., MARTIN, J.L., LIMPALAËR, M., BRUCE, T.J. and PICKETT, J.A., 2013. Responses of herbivore and predatory mites to tomato plants exposed to jasmonic acid seed treatment. Journal of Chemical Ecology, vol. 39, no. 10, pp. 1297-1300. PMid:24057577. http://dx.doi.org/10.1007/s10886-013-0345-5.

SZCZEPANIEC, A., RAUPP, M.J., PARKER, R.D., KERNS, D. and EUBANKS, M.D., 2013. Neonicotinoid insecticides alter induced defenses and increase susceptibility to spider mites in distantly related crop plants. PLoS One, vol. 8, no. 5, pp. e62620. PMid:23658754. http://dx.doi.org/10.1371/journal.pone.0062620.

WELLING, L.L., 2001. Induced resistance: from the basic to the applied. Trends in Plant Science, vol. 6, no. 10, pp. 445-447. PMid:11686134. http://dx.doi.org/10.1016/S1360-1385(01)02046-5. 